\title{
Analisis Keberadaan Coliform dan Escherichia coli pada Es Batu dari Jajanan Minuman di Pasar Tengah Bandar Lampung
}

\author{
Efrida Siti Alifia ${ }^{1)}$ dan Oktira Roka Aji ${ }^{2}$ \\ ${ }^{1}$ Program Studi Biologi, Fakultas Sains dan Teknologi Terapan, Universitas Ahmad Dahlan \\ email: efridasitialifia28@gmail.com \\ ${ }^{2}$ Laboratorium Mikrobiologi, Fakultas Sains dan Teknologi Terapan, Universitas Ahmad Dahlan \\ email: oktira.aji@bio.uad.ac.id
}

APA Citation: Alifia, E, S., Aji, O, R. (2021). Analisis Keberadaan Coliform dan Escherichia coli pada Es Batu dari Jajanan Minuman di Pasar Tengah Bandar Lampung. Quagga: Jurnal Pendidikan dan Biologi, 13(1), 74-81. doi: 10.25134/quagga.v13i1.3698.

Received: 25-11-2020

Accepted: $28-12-2020$

Published: 01-01-2021

\begin{abstract}
Abstrak: Es batu merupakan produk pangan yang dianggap aman untuk dikonsumsi. Es batu biasa dicampurkan pada minuman untuk menambah kesegaran. Es batu dibuat dari air minum yang dibekukan pada suhu $0^{\circ} \mathrm{C}$. Walaupun suhu rendah dapat menghambat pertumbuhan sel mikroorganisme, es batu tetap saja memiliki kemungkinan mengandung mikroorganisme kontaminan. Penelitian ini bertujuan untuk mendeteksi keberadaan Coliform dan Escherichia coli pada es batu dari berbagai minuman yang dijual di Pasar Tengah Bandar Lampung. Metode MPN (Most Probable Number) digunakan untuk menghitung Coliform sedangkan keberadaan bakteri E. coli dideteksi menggunakan media Eosin Methylen Blue Agar (EMB Agar). Sebanyak 8 sampel digunakan pada penelitian ini. Hasil pengamatan menunjukkan bahwa semua sampel positif mengandung Coliform dan 3 sampel positif mengandung E.coli. Faktor-faktor yang dapat menjadi sumber cemaran seperti bahan baku, alat dan praktik higienitas oleh penjual perlu diperhatikan agar es batu terbebas dari kontaminasi Coliform maupun E.coli.
\end{abstract}

Kata kunci: Coliform, E. coli, MPN.

\begin{abstract}
Ice cubes are a food product that is considered safe for consumption. Ice cubes are usually mixed with drinks to increase freshness. Ice cubes are made from drinking water which is then frozen at $0{ }^{\circ} \mathrm{C}$. Although low temperatures can inhibit the growth of microbial cells, ice cubes still have the possibility of containing microbial contaminants. This study aims to detect the presence of Coliform and Escherichia coli in ice cubes from various beverages sold in Pasar Tengah Bandar Lampung. The MPN (Most Probable Number) method was used to calculate Coliform, while the presence of E. coli was detected using Eosin Methylene Blue Agar (EMB Agar) media. A total of 8 samples were used in this study. The results showed that all samples were positive for Coliform and 3 samples were positive for E. coli. Factors that can be a source of contamination such as raw materials, tools and hygiene practices by sellers need to be considered so that ice cubes are free from Coliform and E. coli contamination.
\end{abstract}

Keywords: Coliform, E. coli, MPN.

\section{PENDAHULUAN}

Es batu merupakan produk pangan yang dibuat dari air yang dibekukan. Es batu biasanya dicampurkan pada minuman sebagai bahan pelengkap sehingga minuman tersebut terasa lebih segar (Sukawaty dkk, 2016). Bahan baku pembuatan es batu adalah air bersih yang harusnya melewati proses pemasakan terlebih dahulu sehingga higienis dan memenuhi standar sanitasi (Hadi dkk, 2014). Air yang digunakan sebagai bahan baku pembuatan es batu harus memenuhi syarat mutu yang sama dengan air minum (Nurmalasari dkk, 2019). Rendahnya suhu es batu dianggap mampu menghambat pertumbuhan mikroorganisme karena semua reaksi metabolisme mikroorganisme yang dikatalis oleh enzim sangat dipengaruhi oleh suhu (Jay, 2000). Namun, seringkali ditemukan es batu dibuat dari air tanpa proses pemasakan terlebih dahulu sehingga dapat tercemar oleh mikroorganisme (Afriyanti, 2019). Bahan pangan yang tercemar mikroorganisme dapat membahayakan kesehatan manusia (Aerita dkk, 2014).

Pada penelitian yang dilakukan oleh Hadi dkk pada tahun 2014 di Kota Padang, menunjukkan adanya cemaran bakteri Coliform pada 8 dari 9 sampel es batu rumah tangga yang 
dijual di pasaran Kota Padang. Es batu tersebut memiliki nilai indeks MPN sekitar 9 sampai > 979/100 ml. Es batu yang mengandung Coliform tidak layak untuk dikonsumsi karena dapat menjadi sumber pembawa penyakit, terutama penyakit enterik. Begitu pula hasil penelitian yang dilakukan oleh Sinaga pada tahun $2017 \mathrm{di}$ Kota Medan, menunjukan adanya cemaran bakteri Coliform pada 6 dari 8 sampel es batu kristal yang diambil dari pedagang di Jalan Kapten Muslim Kota Medan. Es batu kristal tersebut memiliki nilai indeks MPN 240/100 ml, 6 sampel tersebut juga positif terdapat cemaran bakteri E. coli yang dibuktikan dengan uji IMVIC. Rendahnya higienitas bahan baku (air) dan alat yang digunakan dalam proses pembuatan es batu dapat menjadi pemicu keberadaan bakteri pencemar dan menurunkan kualitas es batu (Cahya dkk, 2019).

Es batu harus memenuhi persyaratan sama seperti persyaratan air minum yang diatur dalam Peraturan Menteri Kesehatan Republik Indonesia Nomor 492/Menkes/Per/IV/2010. Aspek yang harus dipenuhi meliputi persyaratan fisik, mikrobiologis, dan kimiawi. Jumlah Coliform dan E. coli dalam air tidak boleh melewati batas yang ditentukan yaitu $0 / 100 \mathrm{ml}$ sampel air. Selain itu, mutu es batu yang layak dikonsumsi juga diatur dalam Standar Nasional Indonesia (SNI) 01-3839-1995.

Bakteri Coliform adalah golongan bakteri intestinal yang hidup didalam saluran pencernaan manusia (Madigan dkk, 2019). Bakteri Coliform digunakan sebagai indikator adanya pencemaran bakteri pada uji kualitas air. Keberadaan bakteri Coliform mengindikasikan adanya kontaminasi dan kondisi sanitasi yang tidak baik pada bahan pangan (Surono dkk, 2018). Semakin sedikit kandungan Coliform, artinya kualitas air semakin baik.

$$
\text { Bakteri E.coli merupakan }
$$

mikroorganisme indikator yang dipakai dalam analisis air untuk menguji adanya cemaran tinja (Pakpahan dkk, 2014). Media penyebaran tinja tidak selalu melalui air yaitu dapat melalui pemindahan pasif dari makanan atau minuman, kegiatan tangan ke mulut dan masuk dalam saluran pencernaan (Melliawati, 2009).

Pasar Tengah merupakan salah satu pasar tradisional yang ramai dikunjungi masyarakat Bandar Lampung. Jumlah pengunjung Pasar Tengah dari tahun 2013-2018 sebanyak 8.63923.875 orang (Disperindag Provinsi Lampung,
2018). Pasar Tengah memiliki luas wilayah sekitar $35.000 \mathrm{~m}^{2}$. Banyak terdapat pedagang di Pasar Tengah, salah satunya pedagang jajanan minuman. Para pedagang rata-rata memiliki tempat yang sempit dengan tingkat kebersihan yang kurang baik. Selain itu, data tentang kualitas mikrobiologis es batu pada jajanan minuman tersebut masih sangat minim. Oleh karena itu, penelitian ini bertujuan menganalisis keberadaan bakteri Coliform dan E.coli pada es batu yang berasal dari minuman yang dijual di Pasar Tengah, Bandar Lampung.

\section{METODOLOGI PENELITIAN}

Penelitian ini dilaksanakan di UPTD

Balai Laboratorium Kesehatan Bandar Lampung. Sampel yang digunakan dalam penelitian ini berjumlah 8 sampel. Pengambilan sampel menggunakan teknik random sampling dan terdapat 8 titik lokasi pedagang jajanan minuman di Pasar Tengah yang diambil sampel es batunya. Penelitian ini terdiri dari 2 tahapan yaitu pengujian keberadaan Coliform dan E.coli. Tahapan pengujian Coliform terdiri dari uji pendugaan dan uji penegasan dengan menggunakan ragam 555 .

\section{Uji pendugaan (Presumtive Test)}

Sebanyak $10 \mathrm{ml}, 1 \mathrm{ml}$ dan $0,1 \mathrm{ml}$ sampel masing-masing dimasukkan ke media LB (Lactose broth) dengan ragam 55 . Sampel yang telah disiapkan sebelumnya ditambahkan pada media lalu diinkubasi pada suhu $35^{\circ} \mathrm{C}$ selama 1 x 24 jam. Hasil positif ditandai dengan adanya gelembung gas yang memenuhi $>10 \%$ tabung durham dan terjadinya perubahan warna atau kekeruhan pada media.

\section{Uji penegasan (Confirmative Test)}

Pada uji ini digunakan media BGLB (Briliant Green Lactosa Broth). Hasil positif dari uji pendugaan dilanjutkan dengan uji penegasan. Sampel dimasukkan pada media BGLB lalu diinkubasi pada suhu $35^{\circ} \mathrm{C}$ selama 1 x 24 jam. Hasil positif ditandai dengan adanya gelembung gas yang memenuhi $>10 \%$ tabung durham dan terjadinya perubahan warna atau kekeruhan pada media. Jumlah tabung yang positif dicatat kemudian digunakan untuk menentukan jumlah bakteri berdasarkan tabel MPN (Most Probable Number).

\section{Uji keberadaan E.coli}

Hasil positif dari uji penegasan dilanjutkan dengan uji keberadaan E.coli. 
Suspensi bakteri dari tabung positif diambil menggunakan ose dan ditanam pada media EMB (Eosin Methylen Blue) dengan teknik streak lalu diinkubasi pada suhu $35^{\circ} \mathrm{C}$ selama 1 x 24 jam. Hasil positif ditandai dengan adanya koloni berwarna hijau metalik. Hasil positif dicatat dan dicocokan dengan tabel MPN (dihitung berdasarkan urutan tabung hasil uji penegasan pada media BGLB yang ditanam pada media EMB agar).

Selain uji mikrobiologis pada sampel es batu, faktor-faktor yang berkaitan dengan hygiene dan sanitasi juga diamati. Faktor hygiene dan sanitasi diperoleh dengan cara pengamatan langsung terhadap lokasi pengambilan sampel es batu dan wawancara dengan penjual. Aspek yang diamati antara lain: asal es batu (beli atau buat sendiri), bahan baku air, wadah penyimpanan, dan alat pemukul es batu.

\section{HASIL DAN PEMBAHASAN}

Uji bakteri Coliform dilakukan dengan dua tahap uji, yaitu uji pendugaan (Presumtive test) dan uji penegasan (Confirmative test). Uji bakteri Coliform ini menggunakan ragam 5-5-5 dengan besar volume sampel yang berbeda, hal tersebut dilakukan untuk mengetahui pertumbuhan bakteri dengan konsentrasi yang berbeda-beda. Menurut Sari dan Apridamayanti (2014), hasil uji pendugaan dinyatakan positif apabila terjadi kekeruhan dalam media LB dan adanya gelembung gas sebanyak $>10 \%$ atau lebih dari volume tabung durham setelah diinkubasi selama 1 x 24 jam. Terbentuknya gelembung gas (Gambar 1.) menunjukkan terjadinya proses fermentasi laktosa menjadi asam laktat dan gas.

A.

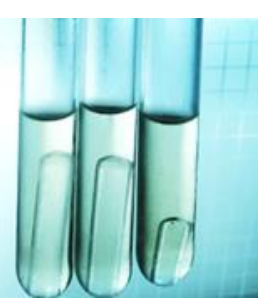

B.

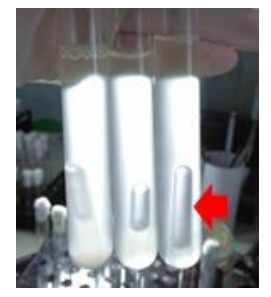

Gambar 1. Hasil uji pendugaan bakteri

Coliform pada media LB (A.) negatif (B.) positif.

Hasil pengamatan pada uji pendugaan dapat dilihat pada Tabel 1. Tabung yang paling banyak menunjukkan hasil positif adalah sampel
A dan D. Hal ini berarti semua tabung dapat dilanjutkan pada uji penegasan. Berdasarkan Tabel 1. Didapatkan 78 dari 120 tabung yang menunjukan hasil positif dan dapat dilanjutkan pada uji penegasan menggunakan media BGLB.

Pada media LB terdapat sumber karbon berupa laktosa. Pada uji ini diasumsikan semua bakteri yang dapat memfermentasi laktosa dapat tumbuh sebab pada media LB tidak terdapat agen selektif khusus (Blood dan Curtis, 1995). Salah satu ciri kelompok bakteri Coliform adalah mampu memfermentasikan laktosa menghasilkan asam dan gas (Davidson dkk, 2004). Namun, bakteri lain juga dapat menfermentasikan laktosa sehingga hasil positif pada uji pendugaan dilanjutkan dengan uji penegasan.

Tabel 1. Hasil Pendugaan Bakteri Coliform

\begin{tabular}{ccccc}
\hline \multirow{2}{*}{$\begin{array}{c}\text { Kode } \\
\text { sampel }\end{array}$} & \multicolumn{3}{c}{$\begin{array}{c}\text { Uji pendugaan } \\
\text { media LB 35 }\end{array}$} & \begin{tabular}{c} 
Jml \\
tabung \\
\cline { 2 - 4 } positif
\end{tabular} \\
\cline { 2 - 5 } & $\mathbf{1 0 ~ \mathbf { ~ m l }}$ & $\mathbf{1 ~ m l}$ & $\mathbf{0 , 1} \mathbf{~ m l}$ & - \\
Kontrol & - & - & - & - \\
$\mathrm{A}$ & +++++ & +++++ & +++++ & $5-5-5$ \\
$\mathrm{~B}$ & +++++ & +++ & - & $5-3-0$ \\
$\mathrm{C}$ & +++++ & +++ & + & $5-3-1$ \\
$\mathrm{D}$ & +++++ & +++++ & +++++ & $5-5-5$ \\
$\mathrm{E}$ & +++++ & ++++ & + & $5-4-1$ \\
$\mathrm{~F}$ & +++++ & + & - & $5-1-0$ \\
$\mathrm{G}$ & +++++ & - & - & $5-0-0$ \\
$\mathrm{H}$ & +++++ & ++++ & + & $5-4-1$ \\
\hline
\end{tabular}

Keterangan:

(+) : Terdapat gelembung gas $>10 \%$ dan media menjadi keruh

(-) : Tidak terdapat gelembung gas dan tidak terjadi kekeruhan pada media
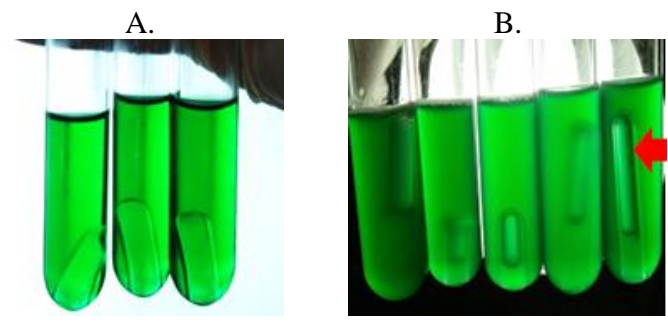

Gambar 2. Hasil uji penegasan bakteri Coliform pada media BGLB (A.) negatif (B.) positif.

Suspensi bakteri dari tabung positif pada uji pendugaan diinokulasikan pada media BGLB (Briliant Green Lactosa Broth). Hasil positif ditandai dengan berubahnya media BGLB menjadi keruh dan terbentuk gelembung gas 
(Gambar 2.). Media BGLB merupakan media selektif dimana pada media tersebut terdapat briliant green dan garam empedu yang dapat menghambat pertumbuhan bakteri gram positif (Blood dan Curtis, 1995). Sumber karbon yang terdapat pada media ini adalah laktosa. Bakteri Coliform akan memfermentasikan laktosa menjadi asam dan gas sehingga hasil positif pada uji ini ditandai dengan terbentuknya gas. Kekeruhan pada media menunjukkan adanya pertumbuhan mikroorganisme.

Berdasarkan pengamatan pada uji penegasan, semua sampel menunjukkan hasil positif (Tabel 2.) Hasil yang telah diperoleh kemudian dibandingkan dengan tabel MPN untuk mendapatkan nilai indeks MPN. Sampel A dan D merupakan sampel dengan indeks MPN tertinggi, yaitu 1600/100 ml sedangkan sampel $\mathrm{G}$ merupakan sampel dengan indeks MPN terendah yaitu 23/100 ml.

Tabel 2. Hasil Penegasan Bakteri Coliform

\begin{tabular}{|c|c|c|c|c|c|}
\hline \multirow{2}{*}{$\begin{array}{c}\text { Kode } \\
\text { sampel }\end{array}$} & \multicolumn{3}{|c|}{$\begin{array}{c}\text { Uji penegasan } \\
\text { media BGLB } 35^{\circ} \mathrm{C}\end{array}$} & \multirow{2}{*}{$\begin{array}{c}\text { Jml } \\
\text { tabung } \\
\text { positif } \\
\end{array}$} & \multirow{2}{*}{$\begin{array}{c}\text { MPN/ } \\
100 \\
\mathrm{ml}\end{array}$} \\
\hline & $10 \mathrm{ml}$ & $1 \mathrm{ml}$ & $0,1 \mathrm{ml}$ & & \\
\hline Kontrol & - & - & - & - & 0 \\
\hline A & +++++ & +++++ & +++++ & $5-5-5$ & 1600 \\
\hline B & +++++ & +++ & - & $5-3-0$ & 79 \\
\hline $\mathrm{C}$ & +++++ & +++ & + & $5-3-1$ & 110 \\
\hline $\mathrm{D}$ & +++++ & +++++ & +++++ & $5-5-5$ & 1600 \\
\hline $\mathrm{E}$ & +++++ & ++++ & + & $5-4-1$ & 170 \\
\hline $\mathrm{F}$ & +++++ & + & - & $5-1-0$ & 33 \\
\hline G & +++++ & - & - & $5-0-0$ & 23 \\
\hline $\mathrm{H}$ & +++++ & ++++ & + & $5-4-1$ & 170 \\
\hline
\end{tabular}

Keterangan:

$(+)$ : Terdapat gelembung gas $>10 \%$ dan media menjadi keruh

(-) : Tidak terdapat gelembung gas dan tidak terjadi kekeruhan pada media

Berdasarkan Peraturan Menteri Kesehatan Republik Indonesia No 492/Menkes/Per/IV/2010, total bakteri Coliform yang diperbolehkan dalam air yaitu $0 / 100 \mathrm{ml}$ sampel. Menurut Supomo dkk (2016), tingginya kandungan Coliform dalam suatu pangan dapat berdampak negatif bagi kesehatan manusia. Besarnya jumlah mikroorganisme pada makanan atau minuman yang dikonsumsi akan menyebabkan timbulnya beberapa penyakit. Pangan dapat menjadi beracun karena telah terkontaminasi oleh bakteri patogen yang kemudian dapat tumbuh dan berkembang biak selama penyimpanan, sehingga mampu memproduksi toksin yang dapat membahayakan manusia.

Bakteri Coliform dikenal sebagai kelompok bakteri yang memiliki ciri-ciri berbentuk batang, gram-negatif, oksidasenegatif, non-spora, dan mampu memfermentasi laktosa dengan produksi gas pada suhu $35-37^{\circ} \mathrm{C}$ setelah inkubasi 48 jam (Medema dkk, 2003; Martin dkk, 2016). Berdasarkan definisi tersebut, termasuk didalamnya 4 genus dari Enterobacteriaceae yaitu Escherichia, Klebsiella, Enterobacter dan Citrobacter (Cabral, 2010). Tidak semua genus tersebut berkaitan langsung dengan cemaran tinja. Meskipun kesemua genus bakteri tersebut dapat hidup di saluran cerna hewan dan manusia, namun beberapa diantaranya dapat ditemukan di lingkungan dan mudah diisolasi dari tanah (Bartram dkk, 1996; Leclerc dkk, 2001). Oleh karena itu, sering dikenal dengan istilah Total Coliform. Untuk memastikan adanya cemaran tinja diperlukan uji keberadaan fecal coliform dimana sebagian besar fecal coliform adalah bakteri E.coli (Cabral, 2010). E.coli merupakan bakteri yang terdapat pada intestinal hewan berdarah panas dan merupakan indikator yang baik yang dapat digunakan untuk mendeteksi adanya cemaran tinja (Leclerc dkk, 2001). Bakteri lain misalnya spesies dari Klebsiella, Enterobacter, dan Citrobacter dapat berasal dari tinja tetapi mereka juga dapat berasal dari lingkungan sehingga menjadikan bakteri tersebut kurang tepat sebagai indikator kontaminasi tinja (Martin dkk, 2016).

Uji pendugaan bakteri E. coli dilakukan dengan cara menginokulasikan sampel positif dari uji penegasan ke media EMB (Eosin Methylen Blue). Media EMB merupakan media selektif differensial yang mengandung eosin $\mathrm{Y}$ dan metilen biru (Blood dan Curtis, 1995). Eosin Y dan metilen biru berfungsi sebagai indikator $\mathrm{pH}$ sekaligus berperan menghambat pertumbuhan bakteri gram positif. E.coli yang diinokulasikan pada media EMB akan memfermentasi laktosa sehingga terbentuk asam. Pada kondisi asam, terbentuk kompleks eosin Y dan metilen biru sehingga menghasilkan koloni berwarna hijau metalik (Leininger dkk, 2001).

Berdasarkan hasil uji pendugaan bakteri E. coli (Tabel 3.), sampel A, B, D, E dan F menunjukkan hasil negatif. Hal ini diketahui dari tidak terlihat adanya koloni berwarna hijau 
metalik dengan kilap logam pada media EMB yang telah diinokulasikan dengan sampel tersebut (Gambar 3.a.). Koloni yang tumbuh berbentuk bulat, berlendir dan berwarna pink keunguan. Menurut Juwita dkk (2014), bakteri gram negatif lain yang dapat tumbuh pada media EMB akan tumbuh dengan ciri koloni berwarna coklat merah muda keunguan dan bakteri yang tidak mampu memfermentasi laktosa akan terlihat merah muda pudar, hal tersebut karena bakteri tersebut lambat dalam memfermentasikan laktosa.

Pada sampel $\mathrm{C}, \mathrm{G}$ dan $\mathrm{H}$ terlihat adanya koloni berwarna hijau metalik dengan kilap logam pada media EMB sehingga diduga terdapat bakteri E. coli. Pada sampel C, G dan $\mathrm{H}$, koloni warna hijau metalik dengan kilap logam terlihat sangat jelas dan memenuhi media (Gambar 3.b.). Berdasarkan Permenkes RI No. 429/ Menkes/Per/IV/2020, air minum tidak boleh mengandung bakteri E.coli $(0 / 100 \mathrm{~mL})$ sehingga sampel $\mathrm{C}, \mathrm{G}$ dan $\mathrm{H}$ belum memenuhi ketentuan tersebut. Keberadaan bakteri E.coli pada bahan pangan menunjukan adanya kontaminasi tinja serta kemungkinan dapat pula mengandung bakteri patogen usus. E.coli merupakan mikroorganisme indikator dimana keberadaannya mengindikasikan adanya bakteri patogen enterik yang terdapat pada tinja yang dapat menimbulkan keracunan pangan (WHO, 2008).

\begin{tabular}{|c|c|c|c|c|c|}
\hline \multirow{2}{*}{$\begin{array}{l}\text { Kode } \\
\text { Sampel }\end{array}$} & \multicolumn{3}{|c|}{$\begin{array}{c}\text { Uji Pendugaan } \\
\text { Media EMB agar } \\
{35^{\circ} \mathrm{C}}^{\circ} \\
\end{array}$} & \multicolumn{2}{|c|}{$\begin{array}{l}\text { Ciri \& } \\
\text { warna } \\
\text { koloni } \\
\end{array}$} \\
\hline & $10 \mathrm{ml}$ & $\begin{array}{c}\mathbf{1} \\
\mathbf{m l}\end{array}$ & $\begin{array}{l}\mathbf{0 , 1} \\
\mathrm{ml}\end{array}$ & $(+)$ & $(-)$ \\
\hline Kontrol & - & - & - & 0 & \\
\hline A & - & - & - & - & (๑) \\
\hline B & - & - & - & - & \\
\hline $\mathrm{C}$ & ++ & - & - & 0 & (อ) \\
\hline D & - & - & - & - & () \\
\hline E & - & - & . & - & () \\
\hline F & - & - & - & - & ( \\
\hline $\mathrm{G}$ & +++++ & - & - & 0 & ๑ \\
\hline $\mathrm{H}$ & +++ & +++ & - & 0 & ๑ \\
\hline
\end{tabular}

Keterangan:

(+) : Sample positif terdapat $E$. coli

(-) : Sample negatif terdapat E. coli

: Koloni bulat, hijau metalik

: Koloni bulat lendir, pink keunguan
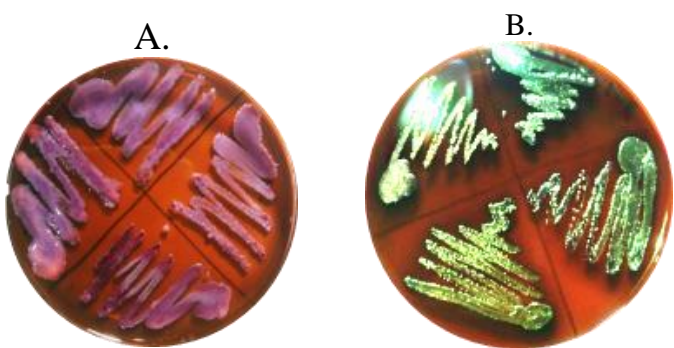

Gambar 3. Hasil uji pendugaan bakteri E.coli pada media EMB agar (A.) negatif (B.) positif.

Meskipun pada sampel A, B, D, E dan F negatif bakteri $E$. coli tetapi hasil uji bakteri Coliform menunjukan hasil positif. Dengan demikian, es batu tersebut belum memenuhi standar kualitas yang telah ditetapkan. Terjadinya cemaran bakteri Coliform dan E.coli pada es batu dapat disebabkan oleh beberapa faktor, diantaranya berasal dari bahan baku, proses pembuatan maupun proses penyimpanan. Keamanan es batu bagi kesehatan harus diperhatikan mulai dari proses pembuatan, pengemasan, pendistribusian dan penyajian (Rifta dkk, 2016).

Cemaran mikroorganisme dapat berasal dari berbagai sumber. Berdasarkan hasil wawancara, beberapa penjual membuat es batu sendiri tetapi ada juga yang membeli dari pemasok es batu. Beberapa diantaranya membuat es batu sendiri dengan bahan baku dari air matang, air minum isi ulang dan air keran. Melalui wawancara diketahui beberapa penjual tidak membuat es batu sendiri sehingga tidak diketahui bahan baku air yang digunakan dalam pembuatan es batu tersebut.

Kontaminasi bakteri dapat terjadi karena tercemarnya bahan baku pembuatan es (Rahman, 2018; Michael dkk, 2010). Berdasarkan data pada Tabel 4, es batu yang dibuat dari air keran (air mentah yang belum direbus) yaitu sampel A mengandung bakteri Coliform dalam jumlah tinggi tetapi negatif bakteri E.coli. Namun, sampel $\mathrm{H}$ yang juga dibuat dari air keran mengandung bakteri Coliform dalam jumlah lebih sedikit tetapi positif mengandung bakteri E.coli. Cemaran bakteri Coliform dan E.coli juga ditemukan pada sampel $\mathrm{C}$ yang dibuat dari air minum isi ulang. Jika dibandingkan dengan sampel $F$ yang dibuat dari air yang sudah direbus, jumlah kandungan Coliform lebih sedikit dan tidak mengandung E.coli. Dengan demikian, pada penelitian ini penggunaan bahan baku berupa air matang yang 
sudah direbus menunjukkan cemaran bakteri yang lebih sedikit dibandingkan dengan sumber bahan baku air yang lain.

Sumber kontaminasi bakteri juga dapat berasal dari alat yang digunakan untuk menyiapkan, membuat, menyimpan dan menyajikan es batu (Isnawati, 2012; Rahman, 2018) Berdasarkan Tabel 4, alat penghancur es batu yang digunakan oleh penjual adalah palu besi, palu stainless dan batu cobek. Alat tersebut jika tidak dijaga kebersihannya misalnya dengan dicuci teratur atau dilapisi plastik maupun lap kain bersih dapat menjadi sumber cemaran mikroorganisme (Nadanti, 2015).

Semua penjual yang diwawancarai menggunakan termos es sebagai wadah es batu. Proses penyimpanan es batu pada wadah yang tidak tertutup rapat kemungkinan menyebabkan serangga vektor penyakit dapat hinggap (Rifta dkk, 2016). Serangga vektor penyakit misalnya lalat dapat membawa bakteri yang kemudian hinggap pada es batu yang tidak ditutup rapat atau yang tidak dikemas baik (Mirawati, 2014). Wadah penyimpanan es batu juga dapat menjadi salah satu sumber kontaminasi bakteri jika tidak dibersihkan dengan benar (Kamelia, 2018). Kebersihan wadah penyimpanan es batu dipengaruhi oleh frekuensi pencucian wadah yaitu sebaiknya dicuci dengan sabun sebelum dan setelah digunakan (Rifta dkk, 2016). Berdasarkan wawancara dengan penjual, alatalat tersebut rata-rata dicuci setiap 2 kali sehari tetapi tanpa menggunakan sabun. Proses pencucian yang tidak tepat tersebut dapat menyebabkan es batu yang disimpan didalamnya terkontaminasi.

Tabel 4. Hasil Wawancara

\begin{tabular}{|c|c|c|c|c|c|c|}
\hline \multirow[b]{2}{*}{ 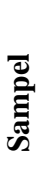 } & \multirow[b]{2}{*}{ 离 } & \multirow[b]{2}{*}{ 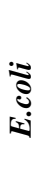 } & \multicolumn{4}{|c|}{ Hasil wawancara } \\
\hline & & & 畓 & 㿣 & 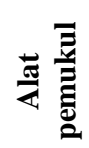 & $\frac{\text { हj }}{\frac{\pi}{\pi}}$ \\
\hline A & 1600 & - & $\begin{array}{c}\text { Sendir } \\
\mathrm{i}\end{array}$ & $\begin{array}{c}\text { Air } \\
\text { keran }\end{array}$ & $\begin{array}{l}\text { Palu } \\
\text { Besi }\end{array}$ & $\begin{array}{c}\text { Termos } \\
\text { es }\end{array}$ \\
\hline B & 79 & - & Beli & $\begin{array}{c}\text { Tidak } \\
\text { diketahu } \\
\text { i }\end{array}$ & $\begin{array}{c}\text { Palu } \\
\text { Besi } \\
\text { Stainl } \\
\text { ess }\end{array}$ & $\begin{array}{c}\text { Termos } \\
\text { es }\end{array}$ \\
\hline $\mathrm{C}$ & 110 & + & $\underset{\mathrm{i}}{\text { Sendir }}$ & $\begin{array}{c}\text { Air } \\
\text { minum } \\
\text { isi ulang }\end{array}$ & $\begin{array}{l}\text { Palu } \\
\text { Besi }\end{array}$ & $\begin{array}{c}\text { Termos } \\
\text { es }\end{array}$ \\
\hline D & 1600 & - & Beli & $\begin{array}{c}\text { Tidak } \\
\text { diketahu } \\
\text { i }\end{array}$ & $\begin{array}{c}\text { Batu } \\
\text { Cobek }\end{array}$ & $\begin{array}{c}\text { Termos } \\
\text { es }\end{array}$ \\
\hline $\mathrm{E}$ & 170 & - & Beli & $\begin{array}{c}\text { Tidak } \\
\text { diketahu } \\
\text { i }\end{array}$ & $\begin{array}{l}\text { Palu } \\
\text { Besi }\end{array}$ & $\begin{array}{c}\text { Termos } \\
\text { es }\end{array}$ \\
\hline
\end{tabular}

\begin{tabular}{|c|c|c|c|c|c|c|}
\hline $\mathrm{F}$ & 33 & - & $\begin{array}{l}\text { Sendir } \\
\mathrm{i}\end{array}$ & $\begin{array}{c}\text { Air yang } \\
\text { sudah } \\
\text { direbus }\end{array}$ & $\begin{array}{l}\text { Palu } \\
\text { Besi }\end{array}$ & $\begin{array}{c}\text { Termos } \\
\text { es }\end{array}$ \\
\hline G & 23 & + & Beli & $\begin{array}{c}\text { Tidak } \\
\text { diketahu } \\
\text { i }\end{array}$ & $\begin{array}{l}\text { Palu } \\
\text { Besi }\end{array}$ & $\begin{array}{c}\text { Termos } \\
\text { es }\end{array}$ \\
\hline $\mathrm{H}$ & 170 & + & $\begin{array}{c}\text { Sendir } \\
\mathrm{i}\end{array}$ & $\begin{array}{c}\text { Air } \\
\text { keran }\end{array}$ & $\begin{array}{l}\text { Palu } \\
\text { Besi }\end{array}$ & $\begin{array}{c}\text { Termos } \\
\text { es }\end{array}$ \\
\hline
\end{tabular}

Selain alat dan bahan yang digunakan, kebersihan diri (personal hygiene) juga merupakan faktor penting. Tidak jarang banyak penjual yang kerap abai untuk menjaga kebersihan diri (Rifta dkk, 2016). Kebiasaan yang sering diabaikan oleh penjual misalnya mencuci tangan dengan sabun sebelum menyajikan minuman es yg dijualnya (Rahman, 2018). Rendahnya praktik hygiene perorangan ini dipengaruhi oleh rendahnya pengetahuan penjual terhadap praktik tersebut sehingga menimbulkan adanya cemaran bakteri pada bahan pangan yang dijajakan (Rifta dkk, 2016). Berdasarkan statistik penyakit bawaan makanan dan minuman, $60 \%$ kasus water and food related disease yang ada disebabkan oleh buruknya teknik penanganan makanan dan minuman, serta terkontaminasi pada saat disajikan di tempat pengelolaan (Djaja, 2000).

\section{SIMPULAN}

Berdasarkan data yang didapat dari hasil penelitian yang telah dilakukan maka dapat diambil kesimpulan yaitu semua sampel es batu positif mengandung bakteri Coliform. Cemaran bakteri $E$. coli terdapat pada 3 sampel yaitu sampel C, G dan H. Dengan demikian, semua sampel belum memenuhi standar Permenkes No. 492/Menkes/Per/IV/ 2010 yang mensyaratkan Coliform dan bakteri E.coli harus 0/100 mL.

\section{UCAPAN TERIMA KASIH}

Ucapan terima kasih diberikan kepada UPTD Balai Laboratorium Kesehatan Bandar Lampung dan semua pihak yang membantu jalannya penelitian ini.

\section{REFERENSI}

Aerita, A.N., Pawenang, E.T., dan Mardiana. 2014. Hubungan higiene pedagang dan sanitasi dengan kontaminasi Salmonella pada daging ayam potong. Unnes Journal of Public Health. 3(4).

Afriyanti, L.N. 2019. Keberadaan Escherichia coli pada makanan di kantin Sekolah 
Dasar. Higeia Journal of Public Health Research and Development. 3(3).

Bartram, J. dan Pedley, S. 1996. Microbiological analyses. In Water Quality Monitoring: A Practical Guide to the Design and Implementation of Freshwater Quality Studies and Monitoring Programmes (J. Bartram and R. Ballance, eds), E \& FN Spon for UNEP and WHO. $237-62$.

Blood, R. M., dan Curtis, G. D. 1995. Media for 'total' Enterobacteriaceae, Coliforms and Escherichia coli. International journal of food microbiology. 26(1): 93-115.

Cabral, J. P. 2010. Water microbiology. Bacterial pathogens and water. International journal of environmental research and public health.7(10): 36573703.

Cahya, T., Amir, M., Manalu R.T. 2019. Uji cemaran mikroba es batu pada penjual minuman di lingkungan Pasar Kecamatan Jagakarsa, Jakarta Selatan. Sainstech Farma. 12 (2): 78-84.

Davidson, P. M., Roth, L. A., dan GambrelLenarz, S. A. 2004. Coliform and other indicator bacteria, in Standard Methods for the Examination of Dairy Products, 17th Edn, eds H. M. Wehr and J. F. Frank.Washington, DC: American Public Health Association. 187-227.

Disperindag (Dinas Perindustrian dan Perdagangan) Provinsi Lampung. 2018. Laporan Kerja Instansi Pemerintah. Lampung: Disperindag.

Djaja I. M., Aryastami N. K. 2000. Pengaruh tempat pengelolaan makanan terhadap kontaminasi makanan di Jakarta Selatan 1999-2000. Jakarta: Badan Penelitian dan Pengembangan Kesehatan, Departemen Kesehatan.

Hadi B., Bahar E., Semiarti R. 2014. Uji bakteriologis es batu rumah tangga yang digunakan penjual minuman di Pasar Lubuk Buaya Kota Padang. Jurnal Kesehatan Andalas. 3(2).

Isnawati. 2012. Hubungan higiene dan sanitasi keberadaan bakteri Coliform dalam es jeruk di warung makan Kelurahan Tembalang Semarang. Jurnal Kesehatan Masyarakat. 1(2).
Jay, J. M. 2000. Modern Food Microbiology, Sixth Edition. Maryland: Aspen Publishers, Inc.

Juwita U., Haryani Y., Jose C. 2014. Jumlah bakteri Coliform dan deteksi Escherichia coli pada daging ayam di Pekanbaru. JOM FMIPA. 1(2).

Kamelia M., Anggoro, B.S., dan Sa'adah, F.P. 2018. Analisis kualitas es batu berdasarkan kandungan Coliform di kantin uin raden intan lampung. BIOSFER Jurnal Tadris Pendidikan Biologi. 9 (1): 61-71.

Leclerc, H., Mossel, D.A., Edberg, S.C., dan Struijk, C.B. 2001. Advances in the bacteriology of the coliform group: their suitability as markers of microbial water safety. Annu Rev Microbiol. 55:201-34.

Leininger, D.J., Roberson, J.R., dan Elvinger, F. 2001. Use of eosin methylene blue agar to differentiate Escherichia coli from other gram-negative mastitis pathogens. Journal of Veterinary Diagnostic Investigation. 13(3):273-5.

Madigan, M. T., Bender, K.S., Buckley, D.H., Stahl, D.A., dan Sattley, W.M. 2019. Brock biology of microorganisms. New York : Pearson.

Martin, N.H., Trmčić, A., Hsieh, T.H., Boor, K.J., dan Wiedmann, M. 2016. The Evolving Role of Coliforms As Indicators of Unhygienic Processing Conditions in Dairy Foods. Front Microbiol. 30(7):1549.

Medema, G.J., Payment, P., Dufour, A., Robertson, W., Waite, M., Hunter, P., Kirby, R., Anderson, Y., 2003. Assessing Microbial Safety of Drinking Water Improving Approaches and Method. London, UK: WHO \& OECD, IWA Publishing. 11-45.

Melliawati, R. 2009. Escherichia coli dalam kehidupan manusia. Biotrends. 4(1).

Michael, O.P., dan Rusmana, D. 2010. Kehadiran bakteri Coliform dalam es batu pada tiga rumah makan ayam goreng siap saji di Bandung. Jurnal Kedokteran Maranatha. 9(2).

Mirawati, M., Lestari, E., dan Djajaningrat, H. 2014. Identifikasi Salmonella pada jajanan yang dijual di kantin dan luar kantin sekolah dasar. Jurnal Ilmu dan Teknologi Kesehatan.1(2). 
Nadanti, A. 2015. Gambaran higiene sanitasi pengolahan es buah yang terkontaminasi bakteri Coliform di Kelurahan Pisangan Kota Tangerang Selatan. Skripsi. Fakultas Kedokteran dan Ilmu Kesehatan, Prodi Kesehatan Masyarakat, UIN Syarif Hidayatullah Jakarta. Jakarta.

Nurmalasari, E., Yuliawati, S., Kusariana, N., dan Hestiningsih, R. 2019. Perbedaan kualitas jenis es batu berdasarkan kandungan Escherichia coli di warung makan Kelurahan Tembalang. Jurnal Kesehatan Masyarakat. 7(1): 142-148.

Pakpahan, R.S., Picauly, I., dan Mahayasa, I.N.W. 2015. Cemaran Mikroba Escherichia coli dan Total Bakteri Koliform pada Air Minum Isi Ulang. Kesmas: Jurnal Kesehatan Masyarakat Nasional. 9(4).

Rahman, A. dan Rahayu, T. 2018. Kualitas mikrobiologis es batu ditinjau dari ALT dan MPN E.coli di Kecamatan Depok Kabupaten Sleman. Jurnal Prodi Biologi. 7(5): 290-299.

Rifta, R. Budiyono, dan Darundiati Y.H. 2016. Studi identifikasi keberadaan Escherichia coli pada es batu yang digunakan oleh pedagang warung makan di Tembalang. Jurnal Kesehatan Masyarakat 4(2).

Sari R., dan Apridamayanti P. 2014. Cemaran Bakteri Eschericia Coli Dalam Beberapa Makanan Laut Yang Beredar Di Pasar Tradisional Kota Pontianak. Kertika Jurnal Ilmiah Farmasi. 2(2).

Sinaga, E.M. 2017. Identifikasi bakteri Escherichia coli pada es kristal dengan menggunakan metode Most Probable Number (MPN) yang diperjualbelikan oleh pedagang di Jalan Kapten Muslim Medan tahun 2017. Jurnal Mutiara Kesehatan Masyarakat, 10(7): 41-47.

Sukawaty, Y., Kamil, M., dan Kusumawati, E. 2016. Uji cemaran bakteri Coliform pada minuman air tebu. Jurnal Ilmiah Manuntung, 2(2), 248-253.

Supomo, Kusumawati E., Amin M. 2016. Uji cemaran Coliform pada ice coffee blended yang beredar di Kecamatan Samarinda Ulu dengan menggunakan metode MPN (Most Probable Number). Jurnal Kebidanan. 2(2): 92-96.

Surono, I.S., Sudibyo, A. dan Waspodo, P. 2018. Pengantar Keamanan Pangan untuk
Industri Pangan. Yogyakarta: Penerbit Deepublish (Grup Penerbitan CV Budi Utama). Hal 59-61.

WHO. 2008. Guidelines for Drinking-water Quality 3rd third Edition. Geneva: WHO Press. 